\title{
EFFECT OF SOME ADDITIVES ON BACTERIOLOGICAL PROPERTIES OF LOCAL MEAT PRODUCT (BASTURMA) DURING STORAGE
}

\author{
N. A. M. Al Marazany ${ }^{\mathrm{a}}$, S. O. Ahmed ${ }^{\mathrm{b}}$, M. B. Al-Aswad ${ }^{\mathrm{b}}$
}

${ }^{\mathrm{a}}$ Dept. of Food Science, College of Agriculture, Sulaimany Univ., Iraq

${ }^{b}$ Dept. of Food Science and Biotechnology, College of Agriculture and Forestry, Mosul Univ., Iraq

*Corresponding auther

\begin{abstract}
Basturma is a traditional meat product manufactured to preserve meat in Iraq. The objective of this study was to determine the influence of adding ascorbic acid, nitrate and nitrite, sodium phosphate, acetic acid and lactic acid on the survival of some microflora during storage period under natural climate conditions. Results demonstrated that the used additives, reduced the growth of some microorganisms studied and eliminated the others during storage depending on the type and concentration of additives. In general, the use of different concentrations of ascorbic acid, nitrate and nitrite and sodium phosphate decreased the total count, coliform, lipolytic and proteolytic bacteria, along the period of storage. When higher concentrations of different additives were used, a complete inhibition of all types of bacteria. The results showed similar patterns at the last months of storage. The treatment of meat trimming before grinding with $5 \%$ of both acetic and lactic acids generally led to the decrease of total count and coliform and a very weak growth of proteolytic bacteria and a complete inhibition of the counts of lipolytic bacteria .
\end{abstract}

\section{INTRODUCTION}

Basturma, an Iraqi meat product, is produced in a large amount in various parts of the country, especially in Mosul city (Nineva province). It is similar to Turkish dry-fermented sausage "Sucuk", Spanish dry fermented sausage "Chorizo" , which is havily smoked, and Greek traditional sausage. The Greek product has to be kept until consumption under cold storage and is characterized as fresh non cooked (like Iraqi basturma) and manufactured under the addition of salt, phosphate, nitrite, ascorbic acid, sugars and different seasoning. They may be partially dried or smoked and should be consumed only after heat processing (frying or grilling) (Papadima and Blouka,1999 and Ambrosiadis et al.,2004)

Basturma is highly regarded among consumers in local markets. However, traditional product does not usually achieve the uniform and consistent quality. This problem seems to be related to the fact that the changes that constituents undergo thoughtout ripening process are not fully understood. These changes contribute to the typical organolebtics of the product.

Basturma in Iraq is produced from lamb, tail fat, salt and spices, however no others additives such as ascorbic acid, nitrate, nitrite, phosphate and organic acids.....etc. Other are added. The production is preferably during the coldest months of the year (autumn, winter and spring) and should be consumed only after heat processing (frying).

The basturma is fermented during the partially drying process under climatic

Part of Msc thesis of the first auther

Received 14/1/2009 accepted 18/2/2009 
conditions. The fermentation was occurred by the inoculation from the raw material or environment during the manufacturing occurred with Turkish sucuk (Bozkurt and Erkmen,2002). Combination of drying and fermentation is known as the ripening period. The main changes take place during this period affects the quality attribute of basturma and continue in the storage period.

The ripening of basturma during storage may be represented by a set of reactions involving proteins, lipids and carbohydrates and many different types of end products are formed, this means that there are several possible sources of contaminations of basturma.

Research on basturma is very limited in the literature. The studies carried out on this product until nowadays refer only to some chemical characteristics, and there is a lack information about the microbiological changes that occur throughout its storage.

Meat and meat products represent an important part of the human diet. Meat is considered to be suitable conditions for the growth of hazardous microorganisms. Microbial contamination can lower the quality of fresh minced meat, shorten its shelf-life. Dorsa, et al. (1998) demonstrated that the most important factor contributing to source and level of microbial contamination of ground beef was the microbial state of raw beef material used for grinding.

However, it could be noted that the content of water and nutritional needs in different meat is considered suitable condition for the growth of microorganisms and may affect the meat safety or produce many toxic compounds (Phillips et al., 2001). For this reason several techniques have been used to preserve meat products and to minimize or to inhibit the growth of these microorganisms.

Many researchers began to refocus attention on the use of some additives like acidulants and other material in the processing of meat trimming destined for ground meat, as a means to provide additional safety for the ground meat-product. Antimicrobial effect of various additives with different concentrations was added to the meat products (Dorsa et al., 1998 and Ellebracht et al., 1999).

An organic acid that has been frequently studied on meat tissus is acetic acid (Hardin et al., 1995). Acetic acid has effective antimicrobial capabilities due to its ability to lower the $\mathrm{pH}$ and cause instability of bacterial cell membrane (Luck and Jager, 1998).

Total count bacteria is considered a good indicator of spoilage of foods like meat products. It is noticed that the use of additives like preservatives and organic acids decrease significantly the total count in ground meat (Stivarius et al., 2002a).

The addition of some preservative materials greatly affects the decreasing coliform bacteria. Pohlman et al. (2002) mentioned that adding sodium phosphate to meat decreased total bacterial count. When $10 \%$ sodium phosphate is used, the amount of total bacterial count decreased from 7.18 to $6.57 \mathrm{log} \mathrm{cfu} / \mathrm{g}$, E.coli from 6.69 to $5.92 \log \mathrm{cfu} / \mathrm{g}$ and coliform bacteria from 6.33 to $5.66 \mathrm{log} \mathrm{cfu} / \mathrm{g}$. However, Stivarius et al. (2002b) found that the addition of some kinds of organic acid, like acetic acid to meat and meat products decreased E.coli and coliform from5.89 and 5.70 to 4.64 and $4.23 \mathrm{log}$ cfu/g, respectively. They also find that the addition of lactic acid (5\%) decreased E.coli and coliform from 6.69 and 6.33,6.03 and 5.63 log $\mathrm{cfu} / \mathrm{g}$, respectively. 
Anderson and Marshall (1990) showed that citric acid in combination with acetic acid, lactic acid and ascorbic acid reduced aerobic plate counts, E.coli and Salmonella Typhimurium.

Nitrate and nitrite are considered a preservative materials and they affect the growth of some microorganisms (Lucke, 1998). Sodium nitrite is widely used as an additive in cured meat where it has important antimicrobial and antibotulinal properties.

Therefore, due to the lack of documentations on the effectiveness of adding some additives, the objective of this study was to evaluate the effects of adding ascorbic acid, nitrate and nitrite, sodium phosphate and some organic acids on some bacteriological properties during storage period (ripening period) of basturma.

\section{MATERIALS AND METHODS}

Preparation of samples: The basturma which was used in this study was prepared according to the traditional procedures and the fermented and drying steps are carried out in rooms subjected to natural climate conditions with sufficient air circulation.

The lean meat (lamb) and tail fat (about 20\%) was cut in small pieces (about $2 \times 2 \times 2 \mathrm{~cm}$ ), then minced. Minced meat (about $4 \mathrm{~mm})$, minced fat, salt $(\mathrm{NaCl}$ about $1.5 \%$ ) and different spices, especially used in the production of basturma in local markets are mixed (hand kneeded) and stuffed after adding the additives into natural animal casings (intestine, locally named "Sundaweel") of about 4-6 cm in diameter and 30-40 cm length. The casings are obtained by cleaning and stripping off the mocus, and muscular layers and usually preserved by drying. After stuffing the basturma spicked over some parts of the surface to allow the entrapped air to escape and after that stored for some hours under heavy materials, then hanged on ropes in storage room.

Treatments and sample processing: The treatments of this study include (1) an untreated control, (2) addition of ascorbic acid, 100, 200 and $300 \mathrm{mg} / \mathrm{kg}$, (3) addition of nitrate and nitrite, $300+100,400+150$, and $500+200 \mathrm{ppm}$, (4) addition of ascorbic acid in combination with nitrate and nitrite, $200 \mathrm{mg} / \mathrm{kg}$ and $400+150 \mathrm{ppm}$, respectively, (5) addition of sodium phosphate, $0.1,0.2$ and $0.3 \%$, (6) $5 \mathrm{~kg}$ of meat trimmings is dipped for two minutes in 5\% solution of lactic acid and acetic acid separately, then minced to prepare the basturma.

Microbiological analysis: The microbiological analysis of all samples are evaluated for total bacteria count coliform, proteolytic and lypolytic bacteria, using the methods mentioned by Harrigan et al., (1976). The bacterial growth is determind as colony forming units (cfu).

The microbiological analysis was: Total bacterial count which determined using nutrient agar (Himedea lab. Pvt. limited, India) incubated at $30^{\circ} \mathrm{C}$ for 2 days, coliform on MacConkey agar which contained bile salts (Himedea lab. Pvt. Limited, India) incubated at $37^{\circ} \mathrm{C}$ for 2 days, proteolytic bacteria on nutrient agar with $10 \%$ of sterilized skim milk incubated at $30^{\circ} \mathrm{C}$ for 3 days and lipolytic bacteria on nutrient agar with $10 \%$ olive oil incubated at $30^{\circ} \mathrm{C}$ for 2 days, then the growth colonies were dipped in zinc sulphate solution and enumerated. All different counts were plated onto growth media in duplicate. 
Statistical analysis: The experiment was conducted in duplicate. Data were analyzed by using the complete randomized design (CRD). The Duncan multiple range test, at level of $(\mathrm{P}<0.05)$, was used to detect differences among means. The data were analyzed using the SAS program (Statistical Analysis System)(2001).

\section{RESULTS AND DISCUSSION}

Changes in different kinds of bacteria in stored basturma: Some kinds of bacteria were studied in basturma product from the beginning of manufacturing and during the storage period under environmental conditions. The total count, coliform, proteolytic and lipolytic bacteria were investigated.

Table (1) shows the amount of the studied bacterial counts in raw minced meat before storage. Total counts were found to be the highest value $\left(2276.50 \times 10^{5}\right.$ $\mathrm{cfu} / \mathrm{g})$, followed by lipolytic $\left(715.00 \times 10^{5} \mathrm{cfu} / \mathrm{g}\right)$, proteolytic $\left(419.00 \times 10^{5} \mathrm{cfu} / \mathrm{g}\right)$ and coli form $\left(54.50 \times 10^{5} \mathrm{cfu} / \mathrm{g}\right)$.

Table (1): Different bacterial groups in raw meat $\left(1 \times 10^{5} \mathrm{cfu} / \mathrm{g}\right)$.

\begin{tabular}{|l|c|}
\hline \multicolumn{1}{|c|}{ Bacterial groups } & Summarized amounts \\
\hline Total count & 2276.50 \\
\hline Coliform bacteria & 54.50 \\
\hline Proteolytic bacteria & 419.00 \\
\hline Lipolytic bacteria & 715.00 \\
\hline
\end{tabular}

Table (2) shows the results of using ascorbic acid, nitrate and nitrite, sodium phosphate, acetic acid and lactic acid on total count bacteria during storage of basturma. Significant changes $(\mathrm{P} .<0.05)$ were observed in different treatments during storage period. The higher amount was in March in the control treatment $\left(1400.00 \times 10^{5} \mathrm{cfu} / \mathrm{g}\right)$, then decreased to $\left(140.00 \times 10^{5} \mathrm{cfu} / \mathrm{g}\right)$ in July. The content in control was the highest in comparison with other treatments.

There was a decrease in total counts during storage period when ascorbic acid and other additives were used This decrease was significant $(\mathrm{P} .<0.05)$ in most of the treatments during the storage period. In the same time it was noticed that with the increase of the concentration of ascorbic acid, the total count was significantly decreased.

The effect of adding nitrate and nitrite was found to be more effective than ascorbic acid. Significant decrease during storage period was found when low concentration was used $(300+100 \mathrm{ppm})$, the bacteria were inhibited completely from the beginning of storage, and when a high concentration was used $(500+200 \mathrm{ppm})$ Also, a significant decrease was noticed during storage period when ascorbic acid was used in combination with nitrate and nitrite .

In general, it was noticed that using sodium phosphate significantly decreased the total count in comparison with control. The decrease was increased with the increase of the concentration.

Table (2) also shows the effect of antimicrobial treatment application before grinding on the microbial characteristics of the ground meat. Acetic acid and lactic acid treatments of meat trimmings before grinding reduced total count in the first 
period of storage and inhibited them at the last two months of storage compared with control. These results are in agreement with Dorsa et al. (1998) and Stivarius et al. (2002a). Acetic acid is considered a preservative material (Luck and Jager, 1998), it has antibacterial effect, because of its ability of lowering the $\mathrm{pH}$.

It is also noticed from the same table that there are different results between the different treatments in the amount of total count. The highest means is noticed in control treatment $\left(766.75 \times 10^{5} \mathrm{cfu} / \mathrm{g}\right)$ followed by the addition of $100 \mathrm{mg} / \mathrm{kg}$ ascorbic acid treatment $\left(336.00 \times 10^{5} \mathrm{cfu} / \mathrm{g}\right)$ and the addition of $0.1 \%$ sodium phosphate treatment $\left(244.25 \times 10^{5} \mathrm{cfu} / \mathrm{g}\right)$. The results are in agreement with Ogden et al. (1997).

Table (2): Effect of storage period and different treatments on total bacterial count $\left(1 \times 10^{5} \mathrm{cfu}^{*} / \mathrm{g}\right)$.

\begin{tabular}{|l|c|c|c|c|c|}
\hline \multicolumn{1}{|c|}{ Treatments } & March & April & May & June & Mean \\
\hline Control & $1400.00 \mathrm{a}$ & $974.00 \mathrm{~b}$ & $563.00 \mathrm{c}$ & $140.00 \mathrm{kl}$ & $766.75 \mathrm{a}$ \\
\hline Ascorbic acid (mg/kg) & & & & & \\
\hline 100 & $499.50 \mathrm{~d}$ & $443.00 \mathrm{e}$ & $340.00 \mathrm{~g}$ & $61.501 \mathrm{~m}$ & $336.00 \mathrm{~b}$ \\
\hline 200 & $370.00 \mathrm{f}$ & $226.00 \mathrm{~h}$ & $65.501 \mathrm{~m}$ & $14.00 \mathrm{n}-\mathrm{p}$ & $168.87 \mathrm{~d}$ \\
\hline 300 & $145.00 \mathrm{kl}$ & $126.50 \mathrm{kl}$ & $26.00 \mathrm{n}-\mathrm{p}$ & $9.00 \mathrm{o} \mathrm{p}$ & $76.62 \mathrm{f}$ \\
\hline Nitrate and nitrite (ppm) & & & & & \\
\hline $300+100$ & $44.00 \mathrm{~m} \mathrm{n}$ & $38.50 \mathrm{~m}-\mathrm{o}$ & $19.00 \mathrm{n}-\mathrm{p}$ & $4.50 \mathrm{p}$ & $26.50 \mathrm{~h}$ \\
\hline $400+150$ & $4.00 \mathrm{p}$ & $2.50 \mathrm{p}$ & ND $\mathrm{N}$ & ND p & $1.62 \mathrm{i}$ \\
\hline $500+200$ & ND p & ND p & ND p & ND p & ND p \\
\hline Combined treatment** & $205.00 \mathrm{~h} \mathrm{i}$ & $184.00 \mathrm{i}$ & $28.50 \mathrm{n}-\mathrm{p}$ & $6.00 \mathrm{o} \mathrm{p}$ & $105.87 \mathrm{e}$ \\
\hline Sodium phosphate $(\%)$ & & & & & \\
\hline \multicolumn{1}{|c|}{0.1} & $460.50 \mathrm{e}$ & $340.50 \mathrm{~g}$ & $150.00 \mathrm{j}$ & $26.00 \mathrm{n}-\mathrm{p}$ & $244.25 \mathrm{c}$ \\
\hline 0.2 & $117.00 \mathrm{k}$ & 80.001 & $14.00 \mathrm{n}-\mathrm{p}$ & $24.00 \mathrm{n}-\mathrm{p}$ & $58.75 \mathrm{~g}$ \\
\hline 0.3 & $30.00 \mathrm{n}-\mathrm{p}$ & $7.00 \mathrm{o} \mathrm{p}$ & ND p & ND p & $9.25 \mathrm{i}$ \\
\hline Acetic acid(\%) & $31.00 \mathrm{n}-\mathrm{p}$ & $16.50 \mathrm{n}-\mathrm{p}$ & ND p & ND p & $11.87 \mathrm{i}$ \\
\hline Lactic acid(\%) & $19.00 \mathrm{n}-\mathrm{p}$ & $6.50 \mathrm{o} \mathrm{p}$ & ND p & ND p & $6.37 \mathrm{i}$ \\
\hline Mean & $255.76 \mathrm{a}$ & $188.07 \mathrm{~b}$ & $92.76 \mathrm{c}$ & $21.15 \mathrm{~d}$ & \\
\hline
\end{tabular}

Means with different letters are significantly different $(\mathrm{P}<0.05)$

*Colony forming unit

**Ascorbic acid $(200 \mathrm{mg} / \mathrm{kg})$ combined with nitrate and nitrite $(400+150) \mathrm{ppm}$ ND-Not detected

Effect of adding the additives on coliform bacteria: E.coli 0157:H7 can colonize the intestinal tracts of animals, providing an opportunity for contamination of meat at slaughter E.coli contamination in foods more often associated with animal product, especially ground meat (Buchanan and Doyal ,1997 and Borch and Arinder,2002)..The effects of additives used in this study on coliform bacteria are summarized in Table (3) The highest count were noticed in control .The count of this bacteria was $323.00 \times 10^{5} \mathrm{cfu} / \mathrm{g}$ in March, then significantly decreased to $152.50 \times 10^{5}, 84.50 \times 10^{5}$ and zero cfu/g in April, May and June, respectively. This may be due to the increase in water activity in basturma and the changes took place during storage (Al-Marazany, et al 2008). 
The data indicated that the use of acetic and lactic acids were significantly $(\mathrm{p}<0.05)$ reduced $E$. coli compared to the control .Acetic and lactic acids treatments of meat trimmings before grinding reduced E. coli from $323.00 \times 10^{5} \mathrm{cfu} / \mathrm{g}$ in control to 23.00 and $4.00 \times 10^{5} \mathrm{cfu} / \mathrm{g}$, respectively. these results are in agreement with Dorsa, et al. (1998).

Table (3): Effect of storage period and different treatments on coliform bacteria $\left(1 \times 10^{5} \mathrm{cfu} * / \mathrm{g}\right)$.

\begin{tabular}{|l|c|c|c|c|c|}
\hline \multicolumn{1}{|c|}{ Treatments } & March & April & May & June & Mean \\
\hline Control & $323.00 \mathrm{a}$ & $152.50 \mathrm{~b}$ & $84.50 \mathrm{c}$ & $\mathrm{ND} \mathrm{j}$ & $140.00 \mathrm{a}$ \\
\hline Ascorbic acid (mg/kg) & & & & & \\
\hline 100 & $56.00 \mathrm{~d}$ & $35.00 \mathrm{e}$ & $\mathrm{ND} \mathrm{j}$ & $\mathrm{ND} \mathrm{j}$ & $22.75 \mathrm{~b}$ \\
\hline 200 & $25.50 \mathrm{f}$ & $1.50 \mathrm{ij}$ & $\mathrm{ND} \mathrm{j}$ & $\mathrm{ND} \mathrm{j}$ & $6.75 \mathrm{~d}$ \\
\hline 300 & $\mathrm{ND} \mathrm{j}$ & $\mathrm{ND} \mathrm{j}$ & $\mathrm{ND} \mathrm{j}$ & $\mathrm{ND} \mathrm{j}$ & $\mathrm{ND} \mathrm{f}$ \\
\hline Nitrate and nitrite (ppm) & & & & & \\
\hline $300+100$ & $3.50 \mathrm{i}$ & $\mathrm{ND} \mathrm{j}$ & $\mathrm{ND} \mathrm{j}$ & $\mathrm{ND} \mathrm{j}$ & $0.87 \mathrm{f}$ \\
\hline $400+150$ & $2.00 \mathrm{ij}$ & $\mathrm{ND} \mathrm{j}$ & $\mathrm{ND} \mathrm{j}$ & $\mathrm{ND} \mathrm{j}$ & $0.50 \mathrm{f}$ \\
\hline $500+200$ & $\mathrm{ND} \mathrm{j}$ & $\mathrm{ND} \mathrm{j}$ & $\mathrm{ND} \mathrm{j}$ & $\mathrm{ND} \mathrm{j}$ & $\mathrm{ND} \mathrm{f}$ \\
\hline Combined treatment** & $\mathrm{ND} \mathrm{j}$ & $\mathrm{ND} \mathrm{j}$ & $\mathrm{ND} \mathrm{j}$ & $\mathrm{ND} \mathrm{j}$ & $\mathrm{ND} \mathrm{f}$ \\
\hline Sodium phosphate (\%) & & & & & \\
\hline 0.1 & $36.00 \mathrm{e}$ & $14.00 \mathrm{~g}$ & $\mathrm{ND} \mathrm{j}$ & $\mathrm{ND} \mathrm{j}$ & $12.50 \mathrm{c}$ \\
\hline 0.2 & $11.00 \mathrm{~h}$ & $\mathrm{ND} \mathrm{j}$ & $\mathrm{ND} \mathrm{j}$ & $\mathrm{ND} \mathrm{j}$ & $2.75 \mathrm{e}$ \\
\hline 0.3 & $\mathrm{ND} \mathrm{j}$ & $\mathrm{ND} \mathrm{j}$ & $\mathrm{ND} \mathrm{j}$ & $\mathrm{ND} \mathrm{j}$ & $\mathrm{ND} \mathrm{f}$ \\
\hline Acetic acid (\%) & $23.00 \mathrm{f}$ & $\mathrm{ND} \mathrm{j}$ & $\mathrm{ND} \mathrm{j}$ & $\mathrm{ND} \mathrm{j}$ & $5.75 \mathrm{~d}$ \\
\hline Lactic acid (\%) & $4.00 \mathrm{i}$ & $\mathrm{ND} \mathrm{j}$ & $\mathrm{ND} \mathrm{j}$ & $\mathrm{ND} \mathrm{j}$ & $1.00 \mathrm{f}$ \\
\hline Mean & $37.23 \mathrm{a}$ & $15.61 \mathrm{~b}$ & $6.50 \mathrm{c}$ & $\mathrm{ND} \mathrm{d}$ & \\
\hline
\end{tabular}

Means with different letters are significantly different $(\mathrm{P}<0.05)$

*Colony forming unit

**Ascorbic acid $(200 \mathrm{mg} / \mathrm{kg})$ combined with nitrate and nitrite $(400+150) \mathrm{ppm}$ ND-Not detected

It was also noticed that coliform was eliminated in most treatments during the storage period. A Complete inhibition was noticed in 37 out of 48 treatments. From these treatments, using nitrate and nitrite $(500+200 \mathrm{ppm})$, ascorbic acid (200 $\mathrm{mg} / \mathrm{kg}$ ) in combination with nitrate and nitrite $(400+150 \mathrm{ppm})$ and sodium phosphate $(0.3 \%)$ were the more effective. These results are due to the preservative action of these additives toward coliform, especially when higher concentrations were used.

The highest counts of coliform was found in March $\left(37.23 \times 10^{5} \mathrm{cfu} / \mathrm{g}\right)$, then decreased during storage period till complete inhibition in June. The highest means of the effect of using additives during storage was noticed in control, $\left(140.00 \times 10^{5}\right.$ $\mathrm{cfu} / \mathrm{g})$ followed by the use of $100 \mathrm{mg} / \mathrm{kg}$ ascorbic acid $\left(22.75 \times 10^{5} \mathrm{cfu} / \mathrm{g}\right)$ then the use of $0.1 \%$ sodium phosphate $\left(12.50 \times 10^{5} \mathrm{cfu} / \mathrm{g}\right)$. It is clear that the growth of coliform was low when low concentrations of these additives were used, and complete inhibition took place when high concentrations were used. These results are in agreement with Pohlman, et al. (2002) and Stivarius, et al. (2002). 
Effect of adding the additives on proteolytic bacteria: Table (4) shows the counts of proteolytic bacteria. In control it was $423.50 \times 10^{5} \mathrm{cfu} / \mathrm{g}$ in March, then significantly $(\mathrm{P}<0.05)$ decreased during the storage period and reached $28.50 \times 10^{5}$ $\mathrm{cfu} / \mathrm{g}$ in June. A significant decrease occurred with the increase of ascorbic acid concentration. A complete inhibition of this bacteria was noticed in 30 from 48 treatments. The reason of these results, when higher concentrations of additive used, out of the water activity may be reduced in the same basturma during storage which led to decrease of the possibility of protein proteolysis and increase its percentage especially in May and June (Al-Marazany, et al. 2008).

Table (4): Effect of storage period and different treatments on proteolytic bacteria $\left(1 \times 10^{5} \mathrm{cfu}^{*} / \mathrm{g}\right)$.

\begin{tabular}{|c|c|c|c|c|c|}
\hline \multicolumn{1}{|c|}{ Treatments } & March & April & May & June & Mean \\
\hline Control & $423.50 \mathrm{a}$ & $277.50 \mathrm{c}$ & $43.50 \mathrm{f}$ & $28.50 \mathrm{~h} \mathrm{i}$ & $193.25 \mathrm{a}$ \\
\hline Ascorbic acid $(\mathrm{mg} / \mathrm{kg})$ & & & & & \\
\hline 100 & $298.00 \mathrm{~b}$ & $209.50 \mathrm{~d}$ & $40.00 \mathrm{fg}$ & $14.00 \mathrm{k} 1$ & $149.12 \mathrm{~b}$ \\
\hline 200 & $91.00 \mathrm{e}$ & $35.00 \mathrm{gh}$ & $14.50 \mathrm{klm}$ & ND o & $34.87 \mathrm{c}$ \\
\hline 300 & $14.00 \mathrm{k} \mathrm{l}$ & $6.50 \mathrm{mno}$ & $1.50 \mathrm{o}$ & ND o & $5.50 \mathrm{e} \mathrm{f}$ \\
\hline Nitrate and nitrite $(\mathrm{ppm})$ & & & & & \\
\hline $300+100$ & $24.00 \mathrm{i} \mathrm{j}$ & $6.50 \mathrm{mno}$ & $0.50 \mathrm{o}$ & ND o & $7.75 \mathrm{e}$ \\
\hline $400+150$ & ND o & ND o & ND o & ND o & ND g \\
\hline $500+200$ & ND o & ND o & ND o & ND o & ND g \\
\hline Combined treatment** & $6.50 \mathrm{mno}$ & ND o & ND o & ND o & $1.62 \mathrm{~g}$ \\
\hline Sodium phosphate $(\%)$ & & & & & \\
\hline 0.1 & $33.00 \mathrm{~h}$ & $19.50 \mathrm{j} \mathrm{k}$ & ND o & ND o & $14.12 \mathrm{~d}$ \\
\hline 0.2 & $9.00 \mathrm{l}-\mathrm{o}$ & $4.00 \mathrm{jk}$ & ND o & ND o & $3.25 \mathrm{f} \mathrm{g}$ \\
\hline 0.3 & ND o & ND o & ND o & ND o & ND g \\
\hline Acetic acid(\%) & ND o & ND o & ND o & ND o & ND g \\
\hline Lactic acid(\%) & ND o & ND o & ND o & ND o & ND g \\
\hline Mean & $69.15 \mathrm{a}$ & $42.57 \mathrm{~b}$ & $7.61 \mathrm{c}$ & $3.26 \mathrm{~d}$ & \\
\hline
\end{tabular}

Means with different letters are significantly different $(\mathrm{P}<0.05)$

*Colony forming unit

**Ascorbic acid $(200 \mathrm{mg} / \mathrm{kg})$ combined with nitrate and nitrite $(400+150) \mathrm{ppm}$ ND-Not detected

Effect of adding the additive on lipolytic bacteria: The results in Table (5) revealed that the highest counts of lypolytic bacteria was noticed in control in March $\left(214.50 \times 10^{5} \mathrm{cfu} / \mathrm{g}\right)$ and decreased in the same month when the additives were used. The amount of fat in the same basturma was increased during storage period and the lipolytic bacteria was decreased because of the decrease of water activity and the increase of total solids in control treatment and the use of some additives in other treatments (Al-Marazany, et al. 2008).

Table (5): Effect of storage period and different treatments on lypolytic bacteria $\left(1 \times 10^{5} \mathrm{cfu}^{*} / \mathrm{g}\right)$. 


\begin{tabular}{|c|c|c|c|c|c|}
\hline Treatments & March & April & May & June & Mean \\
\hline Control & $214.50 \mathrm{a}$ & $145.00 \mathrm{c}$ & $91.50 \mathrm{f}$ & 35.501 & $121.37 \mathrm{a}$ \\
\hline \multicolumn{6}{|l|}{ Ascorbic acid (mg/kg) } \\
\hline 100 & $109.50 \mathrm{~d}$ & $93.00 \mathrm{f}$ & $44.50 \mathrm{i}$ & $10.00 \mathrm{no}$ & $64.25 \mathrm{c}$ \\
\hline 200 & $65.00 \mathrm{~g}$ & $54.00 \mathrm{~h}$ & $12.50 \mathrm{n}$ & ND p & $32.87 \mathrm{~d}$ \\
\hline 300 & $23.501 \mathrm{~m}$ & $10.50 \mathrm{n}$ & $3.00 \mathrm{p}$ & ND p & $9.25 \mathrm{~g}$ \\
\hline \multicolumn{6}{|l|}{$\begin{array}{l}\text { Nitrate and nitrite } \\
(\mathrm{ppm})\end{array}$} \\
\hline $300+100$ & $44.50 \mathrm{i}$ & $14.50 \mathrm{n}$ & $2.00 \mathrm{p}$ & $\mathrm{ND} p$ & $15.00 \mathrm{f}$ \\
\hline $400+150$ & $19.50 \mathrm{~m}$ & $14.00 \mathrm{n}$ & ND p & ND p & $5.87 \mathrm{~h}$ \\
\hline $500+200$ & ND p & ND p & ND p & ND p & ND i \\
\hline Combined treatment** & $44.50 \mathrm{i}$ & $14.00 \mathrm{n}$ & $5.00 \circ \mathrm{p}$ & $1.50 \mathrm{p}$ & $16.00 \mathrm{f}$ \\
\hline \multicolumn{6}{|l|}{ Sodium phosphate (\%) } \\
\hline 0.1 & $172.00 \mathrm{~b}$ & $99.00 \mathrm{e}$ & $26.50 \mathrm{k} 1$ & $12.00 \mathrm{n}$ & $77.37 \mathrm{~b}$ \\
\hline 0.2 & $46.50 \mathrm{i}$ & $30.00 \mathrm{k}$ & $2.50 \mathrm{p}$ & ND p & $19.45 \mathrm{e}$ \\
\hline 0.3 & ND $p$ & ND p & ND p & ND p & ND i \\
\hline Acetic acid(\%) & $4.00 \mathrm{p}$ & ND p & ND p & ND p & $1.00 \mathrm{i}$ \\
\hline Lactic acid(\%) & ND p & ND p & ND p & ND p & ND i \\
\hline Mean & $57.11 \mathrm{a}$ & $35.53 \mathrm{~b}$ & $14.42 \mathrm{c}$ & $4.53 \mathrm{~d}$ & \\
\hline
\end{tabular}

Means with different letters are significantly different $(\mathrm{P}<0.05)$

*Colong forming unit

**Ascorbic acid $(200 \mathrm{mg} / \mathrm{kg})$ combined with nitrate and nitrite $(400+150) \mathrm{ppm}$ ND-Not detected

In general, the amount of lipolytic bacteria decreased significantly $(\mathrm{P}<0.05)$ when additives used in comparison with the control. The results indicated that with the increase of ascorbic acid concentration, the amount of lipolytic bacteria were significantly decreased in comparison with the control. It was $109.50 \times 10^{5} \mathrm{cfu} / \mathrm{g}$ in March when $100 \mathrm{mg} / \mathrm{kg}$ of ascorbic acid was used, then decreased to $65.00 \times 10^{5}$ and $23.50 \times 10^{5} \mathrm{cfu} / \mathrm{g}$ when 200 and $300 \mathrm{mg} / \mathrm{kg}$ was used, respectively. This situation continued in the other months of storage till the complete inhibition in June when the last two concentrations were used. The same results (significant decrease during storage) were noticed when nitrate and nitrite was used, and also with the increase of their concentration. Furthermore, the increase of inhibiting the lipolytic bacteria during storage period and with the increasing of the concentration of nitrate and nitrite was higher in comparison with using ascorbic acid. A complete inhibiting was noticed when higher concentration was used. When ascorbic acid was used in combination with nitrate and nitrite, the amount of lipolytic bacteria was decreased from $44.50 \times 10^{5} \mathrm{cfu} / \mathrm{g}$ in March to $1.5 \times 10^{5} \mathrm{cfu} / \mathrm{g}$ in June.

Sodium phosphate decreased the lipolytic bacteria. With the increase of its concentration, the count were significantly $(\mathrm{P}<0.05)$ decreased in compared to control. The amount of lipolytic was decreased from $214.5 \times 10^{5} \mathrm{cfu} / \mathrm{g}$ in control to 172.00 and $46.5 \times 10^{5} \mathrm{cfu} / \mathrm{g}$ when 0.1 and $0.2 \%$ were used, respectively. A complete inhibition was noticed when $0.3 \%$ used.

The use of nontoxic food-grade chemicals (organic acids) to decrease counts of microorganisms on the meat surface is well documented (Hardin et al. 1995, 
Dorsa et al. 1998 and Ellebracht et al. 1999). The use of organic acids in this research inhibited lipolytic bacteria during the period of storage, except in March when acetic acid used.

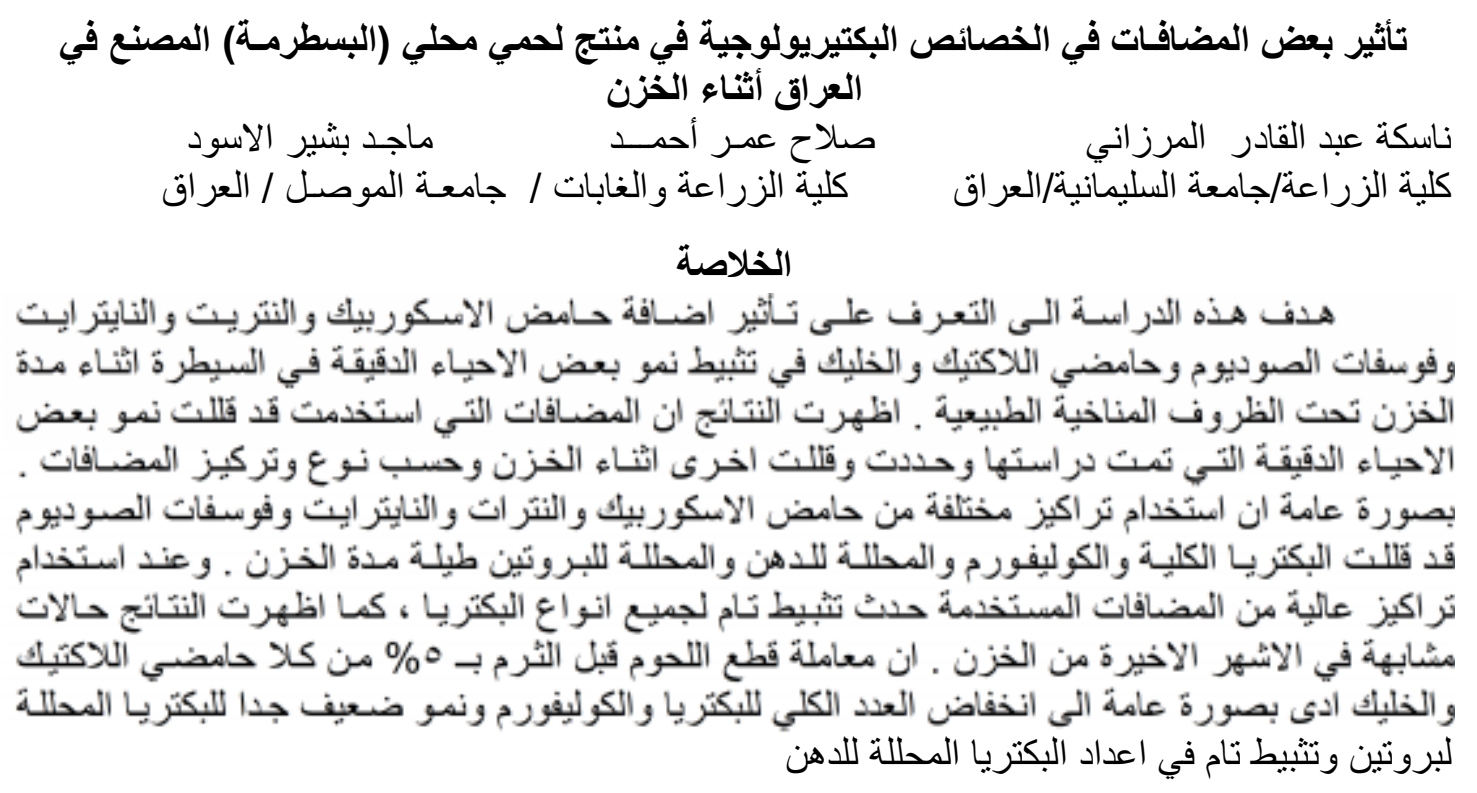

\section{REFERENCES}

Al-Marazany, N.A.M. ,Al-Aswad, M.B.,and Ahmad S.O.(2008).Effect of using some additives on some chemical composition of local basturma during storage,Mesopotamia J.ofAgric,36(1)

,(In press).

Ambrosiadis, J., Soultos, N., Abrahim, A., and Bloukas, J.G. (2004). Physicochemical, microbiological and sensory attributes for the characterization of Greek traditional sausage, Meat Sci., 66,279-287.

Anderson, M.E. and Marshall, R.T. (1990). Reducing microbical populations on beef tissue: concentration and temperature of an acid mixture, J. of Food Sci., 55(4), 903-905.

Borch, J. C., \& Arinder P. (2002). Bacteriological safety issues in red meat and ready-to-eat meat products, as well as control measures. Meat Sci. 62(3), 381390.

Bozkurt, H. and Erkman, O. (2002). Formations of biogenic amines in Turkish style sausage during ripening and storage periods, J. of Food Quality, 25, 317-332.

Buchanan, R.L. and Doyle, M.P. (1997). Foodborne desease significance of Escherichia coli 0157:H7 and other enterohemorrhagic E.coli. Food Technology, 51(10), 69-76.

Dorsa, W. J., Cutter C. N. \& Siragusa G. R. (1998). Bacterial profile of ground beef made from carcass tissue experimentally contaminated with pathogenic and spoilage bacteria before being washed with hot water, alkaline solution, or organic acid and then stored at 4 or $12{ }^{\circ} \mathrm{C}$. J. of Food Protection, 61(9), 11091118 . 
Ellebracht, E. A., Castillo A., Lucia L. M. Miller R. K. \& Acuff G. R. (1999). Reduction of pathogens using hot water and lactic acid on beef trimmings. J. of Food Sci. 64(6), 1094-1099.

Hardin, M.D., Acuff G.R., Lucia L. M., Oman J. S. \& Savell J. W. (1995). Comparison of methods for decontamination from beef carcass surfaces. J. of Food Protection, 58(4), 368-374.

Harrigan, F., Cance M. C. and Margaret E. (1976). Laboratory Methods of Food and Dairy Microbiology. Academic press-London-New-York. San Francisco

Luck, E. \& Jager, M. (1998). In G. F. Edwards (Ed.), Antimicrobial food additives (2nd ed.). New York: Springer-Verlag (pp. 137-144, 116-119, 42-43, 239, 98-101): (C. F. Stivasius et al., (2002). The effects of acetic acid, gluconic acid and trisodium citrate treatment of beef trimmings on microbial, color and odor characteristics of ground beef through simulated retail display. Meat Sci., 60, 245-252.

Lucke, F. K. (1998). Fermented Sausages. In B. J. B. Wood (Ed.), Microbiology of fermented foods (pp. 441-483). London, UK: Blackie Academic \& Professional.

Ogden, Sh. A., Taylor, Ch. Dodd, I., Guerrero, Buendia, H., and Gallardol, F. (1997). Preservative effect of combined propionic and ascorbic acids on pork meat stored at $25^{\circ} \mathrm{C}$. J. of Food Protection. 60,935-942.

Papadima, S.N., and Bloukas, J.G. (1999). Effect of fat level and storage conditions on quality characteristics of traditional Greek sausages, Meat Sci., 51, 103 113.

Phillips, D., Summer, J., Jodie, F., Alexander \& Kym Dutton, M. (2001). Microbiological quality of australian sheep meat. J. of Food Prot., 64, 697-700.

Pohlman, F. W., Stivarius, M. R., McElyea, K. S., Johnson, Z. B., \& Johnson, M. G. (2002). The effects of ozone, chlorine dioxide, cetylpyridinium chloride and trisodium phosphate as multiple antimicrobial interventions on microbiological, instrumental color, and sensory color and odor characteristics of ground beef. Meat Sci., 61, 307-313.

SAS (2001) . SAS/STAT, user's guide for Personal computer, Release 9, SAS. Institute. Inc. Cary. NC. USA.

Stivarius, M. R., Pohlman, F. W., McElyea K. S. \& Apple J. K. (2002). Microbial, instrumental color and sensory color and ador characteristics of ground beef produced from beef trimmings treated with ozone or chlorine dioxide. Meat Sci., 60, 299-305.

Stivarius, M. R., Pohlman, F. W. , McElyea, K. S. \& Apple, J. K. (2002a). The effects of acetic acid, gluconic acid and trisodium citrate treatment of beef trimmings on microbial, color and odor characteristics of ground beef through simulated retail display. Meat Sci. 60, 245-252.

Stivarius, M. R., Pohlman, F. W., McElye, K. S. \& Waldroup A. L. (2002b). Effects of hot water and lactic acid treatment of beef trimmings prior to grinding on microbial, instrumental color and sensory properties of ground beef during display, Meat Sci. $60,327-334$. 